\title{
Effect of the Degree of Hyperglycaemia on the Catalytic Activities of Glycosidases in Kidney and Urine of Diabetic Rats
}

\author{
By Dubravka Juretić, K. Lipovac
}

Institute of Medical Biochemistry, Faculty of Pharmacy and Biochemistry, University of Zagreb, Yugoslavia

\author{
M. Hadžija and M. Slijepčević
}

OOUR Experimental Biology and Medicine, Institute "Ruder Bošković", Zagreb, Yugoslavia

(Received July 1/September 21, 1983)

Summary: The catalytic activities of $\mathrm{N}$-acetyl- $\beta$ - $D$-glucosaminidase, $\beta$-galactosidase and $\alpha$-glucosidase in kidney and urine of diabetic rats were investigated in relation to the duration of diabetes, to the degree of constant hyperglycaemia and to the therapeutic control in the early stage of disease.

The results suggest that the degree of constant hyperglycaemia and the duration of untreated diabetes are significant determining factors for the course of morphological changes. These changes are manifested as a decrease of the glycosidases in kidney ( 0.5 to 0.6 time the age-matched controls) and as moderate to severe enzymurias.

Daily variation of blood glucose with inadequate insulin Lente therapy caused decreased $\mathrm{N}$-acetyl- $\beta-D$ glucosaminidase and $\beta$-galactosidase activities in kidney as well as enzymuria. Since such changes can be correlated with histologically visible changes in the kidney, the measurement of these enzymes in urine is a simple way of monitoring the development of kidney damage in poorly controlled diabetes.

When constant normoglycaemia was maintained for three weeks with insulin Ultralente in diabetic rats with a confirmed decrease of kidney glycosidases, the persisting morphological alteration of the organ was reflected by a urinary output of $\mathrm{N}$-acetyl- $\beta-D$-glucosaminidase.

Einfluß des Hyperglykämie-Grades auf die katalytischen Aktivitäten von Glykosidasen in Nieren und Harn diabetischer Ratten

Zusammenfassung: Die katalytischen Aktivitäten von $\mathrm{N}$-Acetyl- $\beta$ - $D$-glucosaminidase, $\beta$-Galaktosidase und $\alpha$-Glucosidase in Niere und Harn diabetischer Ratten wurden untersucht und in Beziehung gesetzt zur Dauer des Diabetes, zum Grạ einer konstanten Hyperglykämie und zur therapeutischen Kontrolle im Frühstadium der Erkrankung.

Die Ergebnisse weisen darauf hin, daß der Grad konstanter Hyperglykämie und die Dauer eines unbehandelten Diabetes bedeutende Einflußgrößen für den Ablauf morphologischer Veränderungen sind. Die Veränderungen werden manifest als Abfall der Glykosidasen in der Niere auf das 0,5-0,6-fache gleichaltriger Kontrollen und als mäßige bis starke Enzymurien.

Tägliche Änderung der Glucosekonzentration im Blut durch inadäquate Therapie mit Insulin Lente bewirkte erniedrigte katalytische Aktivitäten von N-Acetyl- $\beta$ - $D$-glucosaminidase und $\beta$-Galaktosidase in der Niere als auch Enzymurie. Da solche Änderungen mit histologisch sichtbaren in der Niere korreliert werden können, ist die Bestimmung dieser Enzyme im Harn ein einfacher Weg, die Entwicklung eines Nierenschadens bei schlecht kontrolliertem Diabetes zu verfolgen. 
Wenn bei diabetischen Ratten mit einem bestätigtem Abfall der Glykosidasen in der Niere für 3 Wochen eine konstante Normoglykämie durch Insulin Ultralente gehalten wurde, spiegelte sich die persistierende morphologische Veränderung der Niere durch eine Ausscheidung von N-Acetyl- $\beta$ - $D$-glucosaminidase im Harn wider.

\section{Introduction}

Clinical practice in the past fifty-two years has shown that the lives of diabetics are prolonged by insulin treatment. Thus tissue damage, such as retinopathy and nephropathy, has become a major factor in diabetic life (1).

Changes in the small blood vessels are caused by thickening of basement membrane (2); it is therefore essential for the prevention and treatment of the menacing sequelae of diabetes to clarify its pathogenesis. Because of the importance of glycoproteins as major constituents of basement membrane, their increased production or decreased breakdown has emerged as the central problem in the biochemical research of diabetes $(3,4,5)$.

The purpose of our studies has been to define the changes in the catalytic activities of $\mathrm{N}$-acetyl- $\beta-D$ glucosaminidase (EC 3.2.1.30), $\beta$-galactosidase (EC 3.2.1.23) and $\alpha$-glucosidase (EC 3.2.1.20) in kidney and urine of diabetic rats. The enzymes were previously shown to be operative in the catabolism of the oligo- and polysaccharide moieties of glycoproteins (6). The changes of the catalytic activities of glycosidases in kidney and in urine were investigated in relation to the duration of diabetes, to the degree of hyperglycaemia and to the therapeutic control in the early stage of illness. The catalytic activities of glycosidases in urine proved to be an early biochemical indicator of the beginning of the histologically visible morphological changes in diabetic kidney.

\section{Materials and Methods}

Female Wistar rats, 200-250 g were used in all experiments, and 6-12 rats were used in each experimental group. Diabetes was induced by a single intravenous administration of streptozotocin ( $65 \mathrm{mg} / \mathrm{kg}$ body weight) in citrate buffer at $\mathrm{pH} 4.5$ (Serva, Heidelberg). Both control and diabetic rats were fed on Purina chow and water ad libidum and killed by withdrawing blood from the common iliac vein under ether anesthesia two, five and ten weeks respectively after streptozotocin injection. Rats were placed in metabolic cages and their urines collected for 12 hours before sacrifice.

Groups of six diabetic rats suffering from increased concentration of blood glucose were treated once a day with $4 \mathrm{U} / \mathrm{kg}$ insulin Lente or with $4 \mathrm{U} / \mathrm{kg}$ insulin Ultralente (Galenika, Beograd) for three weeks. All insulin treated diabetic rats received their first daily dose two weeks after induction of diabetes. Consequently, six groups of diabetic rats were studied (fig. 1).

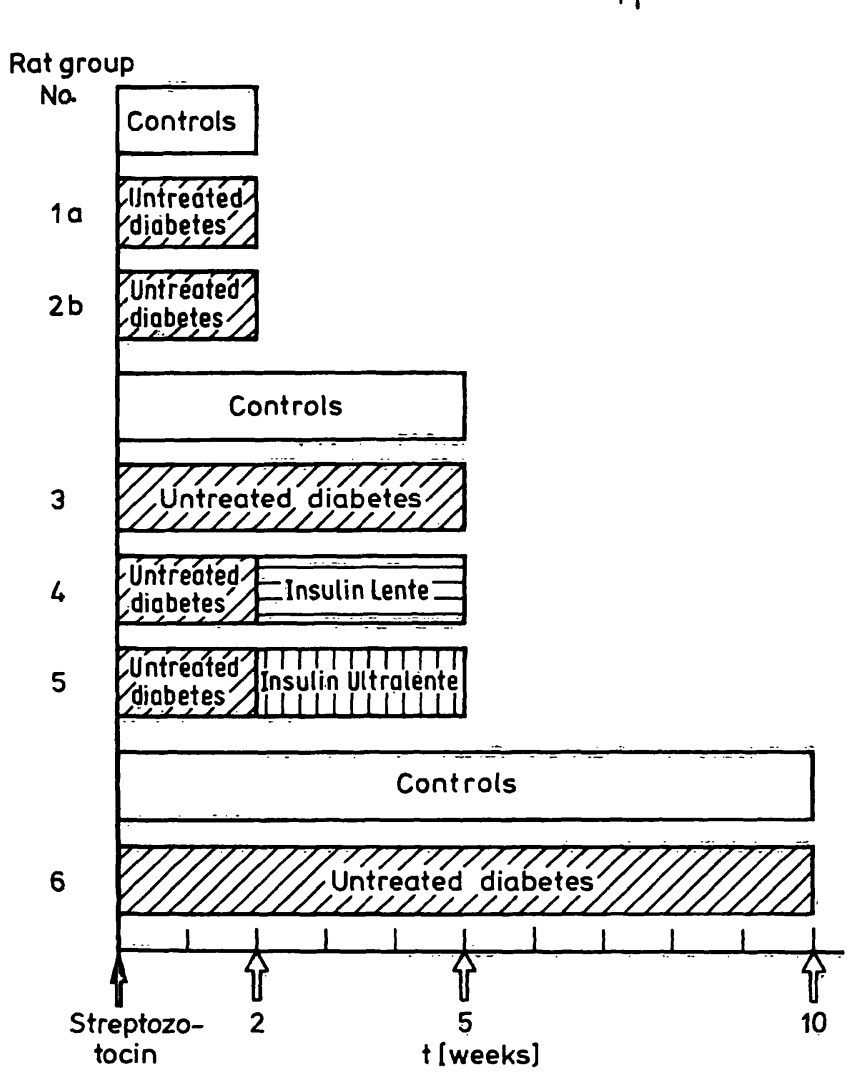

Fig. 1. Schematic presentation of the experimental design in the study of diabetic rats.

$a=$ mild hyperglycaemia $; b=$ severe hyperglycaemia

Group 112 rats after two weeks of untreated diabetes with mild hyperglycaemia

Group 26 rats after two weeks of untreated diabetes with severe hyperglycaemia

Group 36 rats after five weeks of untreated diabetes

Group 46 diabetic rats with mild hyperglycaemia, untreated for two weeks, then supplemented with $4 \mathrm{U} / \mathrm{kg}$ of insulin Lente throughout the three subsequent weeks.

Group 56 diabetic rats with severe hyperglycaemia, untreated for two weeks, then supplemented with $4 \mathrm{U} / \mathrm{kg}$ of insulin Ultralente for the three subsequent weeks.

Group 66 rats after ten weeks of untreated diabetes.

After sacrifice, kidneys were dissected out and washed with icecold $0.15 \mathrm{~mol} / \mathrm{NaCl}$. One of them was homogenized with icecold $0.01 \mathrm{~mol} / \mathrm{l}$ phosphate buffer $\mathrm{pH} 6.0$ in an Ultra Turax homogenizer, type TP 18-10 Janke and Kunkel GK for 1 minute. The homogenates were then centrifuged at $10000 \mathrm{~g}$ for 1 hour at $4^{\circ} \mathrm{C}$ and supernatants were used for enzyme assay. The second kidney was prepared for histological assay.

Glucose "was determined spectrophotometrically by the $o$-toluidine method (7). Urines of control and diabetic rats were tested for glucose and proteins with Multistix (Amés Company, Inc.). 
Glycosidase activities were measured spectrofluorometrically by using 4-methylumbelliferyl substrates (Koch Light, Colnbrook); $\mathrm{N}$-acetyl- $\beta$ - $D$-glucosaminidase was determined by the method of $O$ 'Brien (8), $\beta$-galactosidase by the method of Price (9) and $\alpha$-glucosidase by the method of Salafsky (10).

Mann-Whitney's test was used to compare the groups. Results are presented as mean values with standard deviations.

\section{Results}

Effect of the increasing length of diabetes on the glycosidase activities in kidney and urine

As shown in table 1, the blood glucose concentration of diabetic rats changed with the increasing duration of diabetes. The enlargement of kidney and the raised level of glucose excretion were found to be related to the degree of hyperglycaemia.

The enzyme catalytic activities in the kidney of diabetic rats with mild hyperglycaemia (Group 1) did not change two weeks after induction of diabetes. However, the prolonged duration of diabetes and a higher degree of hyperglycaemia were reflected on the activities of glycosidases. The enzyme catalytic activities in kidney were reduced $(p<0.01)$ below those of the normal age matched controls five weeks after the administration of streptozotocin (Group 3), and remained on the same level even after ten weeks of life when severe hyperglycaemia and glycosuria were also present (Group 6) (figs. 2a, 3a, 4a).

Over the period of observation there was an inverse relationship between the measured catalytic activities of enzymes in the renal tissue and in the urine. Urinary $\beta$-galactosidase activity was increased ( $p$ $<0.01$ ) in rats with mild hyperglycaemia without glycosuria two weeks after administration of streptozotocin. The excretion of $\mathrm{N}$-acetyl- $\beta$ - $D$-glucosamini- dase was also increased in the early phase of diabetes, but the rise was statistically different in the rats with glycosuria, when determined five and ten weeks after streptozotocin injection. Urinary $\alpha$-glucosidase activity was statistically increased only ten weeks after induction of diabetes (figs. $2 b, 3 b, 4 b$ ).

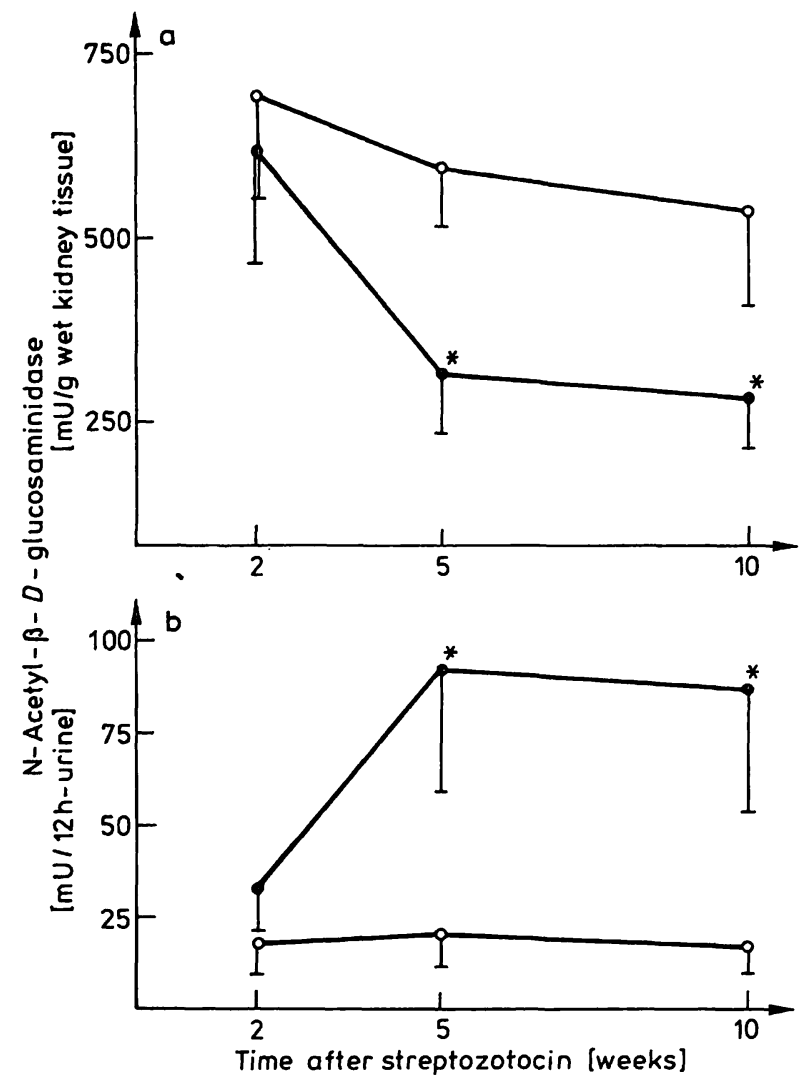

Fig. 2 . The catalytic activities of $\mathrm{N}$-acetyl- $\beta$ - $D$-glucosaminidase in kidney (a) and urine (b) after streptozotocin administration as a function of time.

. Diabetic rats with two weeks of mild hyperglycaemia and severe hyperglycaemia five and ten weeks after treatment (O-O); age-matched controls $(\mathrm{O}-\mathrm{O})$. The values are presented as means $\pm S D *(p<0.01)$.

Tab. 1. Changes of relevant parameters in diabetic rats as a function of time after streptozotocin administration. $a=$ mild hyperglycaemia; $N=$ number of rats. The values are presented as means $\pm S D{ }^{*}(p<0.01)$.

\begin{tabular}{|c|c|c|c|c|c|c|}
\hline $\begin{array}{l}\text { Weeks after } \\
\text { streptozotocin } \\
\text { injection }\end{array}$ & Rat group & $\mathrm{N}$ & $\begin{array}{l}\text { Blood glucose } \\
(\mathrm{mmol} / \mathrm{l})\end{array}$ & $\begin{array}{l}\text { Urine glucose } \\
(\mathrm{mol} / \mathrm{l})\end{array}$ & $\begin{array}{l}\text { Urine volume } \\
(\mathrm{ml})\end{array}$ & $\begin{array}{l}\text { Kidney } \\
\text { weight } \\
\text { (g) }\end{array}$ \\
\hline 2 & $\begin{array}{l}\text { Control } \\
\text { Group } 1\end{array}$ & $\begin{array}{l}6 \\
6\end{array}$ & $\begin{array}{l}7.30 \pm 0.69 \\
9.61 \pm 1.36^{\mathrm{a}}\end{array}$ & $\begin{array}{l}0 \\
0\end{array}$ & $\begin{array}{r}8.1 \pm 3.2 \\
13.5 \pm 5.6\end{array}$ & $\begin{array}{l}0.62 \pm 0.13 \\
0.59 \pm 0.05\end{array}$ \\
\hline 5 & $\begin{array}{l}\text { Control } \\
\text { Group } 3\end{array}$ & $\begin{array}{l}12 \\
12\end{array}$ & $\begin{array}{r}6.23 \pm 1.36 \\
16.50 \pm 4.38\end{array}$ & $\begin{array}{c}0 \\
>0.11\end{array}$ & $\begin{array}{r}7.6 \pm 3.3 \\
51.6 \pm 20.2\end{array}$ & $\begin{array}{l}0.52 \pm 0.04 \\
0.77 \pm 0.11^{*}\end{array}$ \\
\hline 10 & $\begin{array}{l}\text { Control } \\
\text { Group } 6\end{array}$ & $\begin{array}{l}6 \\
6\end{array}$ & $\begin{array}{r}7.35 \pm 0.42 \\
17.20 \pm 3.20\end{array}$ & $\begin{array}{l}0 \\
>0.11\end{array}$ & $\begin{array}{r}5.3 \pm 1.8 \\
42.5 \pm 18.3\end{array}$ & $\begin{array}{l}0.51 \pm 0.04 \\
0.84 \pm 0.06^{*}\end{array}$ \\
\hline
\end{tabular}




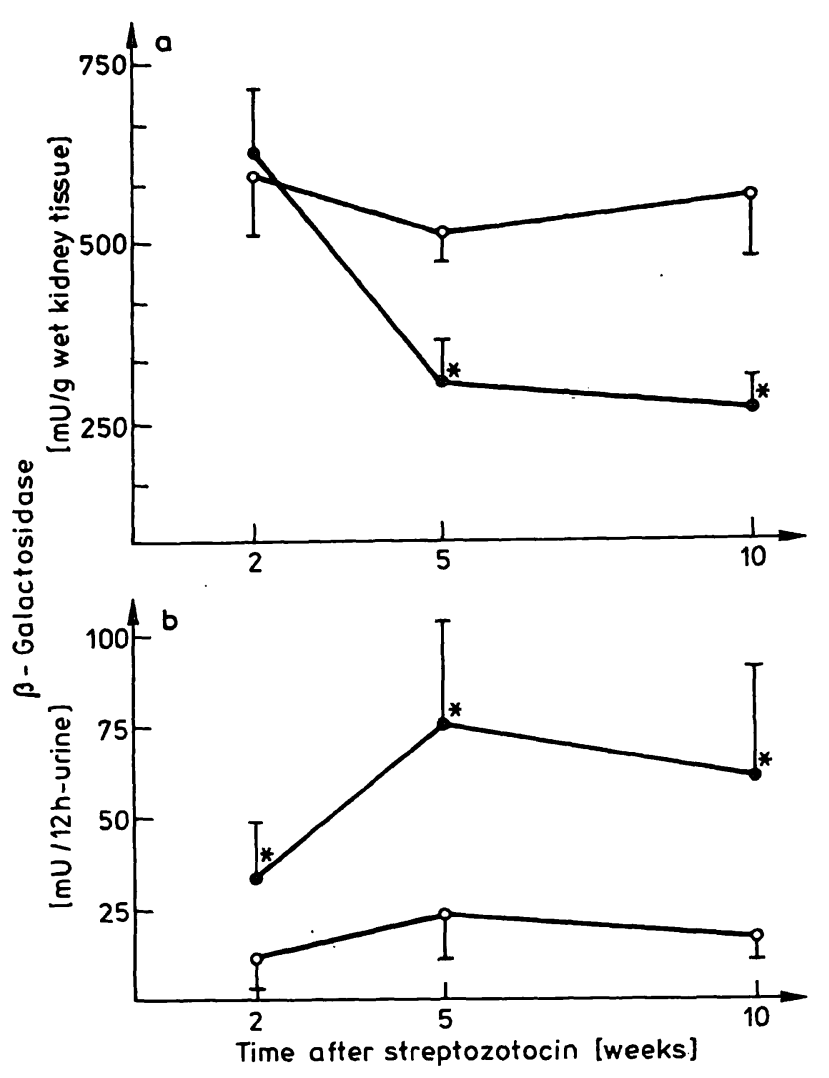

Fig. 3. The catalytic activities of $\beta$-galactosidase in kidney (a) and urine (b) after streptozotocin administration as a function of time.

Diabetic rats with two weeks of mild hyperglycaemia and severe hyperglycaemia five and ten weeks after treatment $(\mathrm{O}-\mathrm{O})$; age-matched controls $(\mathrm{O}-\mathrm{O})$. The values are presented as means $\pm S D .^{*}(p<0.01)$.

Effect of the degree of hyperglycaemia on the glycosidase activities in kidney and urine

Two weeks after streptozotocin injection, group 1 developed a mild hyperglycaemia and showed normal glycosidase activities in kidney. In contrast, in the same period group 2 developed a severe hyperglycaemia and showed decreased activities in the kidney (tab. 2).

The glycosidase activities in the kidneys of the latter group changed in the same manner as in the kidneys of the rats with severe hyperglycaemia five weeks after induction of diabetes (Group 3).

\section{Treatment of diabetic rats with insulin}

The glycaemic control of the two groups of diabetic rats treated with insulin during the experiment is shown in table 3. Three weeks after insulin Lente treatment, the blood glucose concentration increased from $9.61 \pm 1.36 \mathrm{mmol} / \mathrm{l}$ to $18.6 \pm 4.50$ $\mathrm{mmol} / \mathrm{l}$ (Group 4 ), while in group 5 , which was treat-

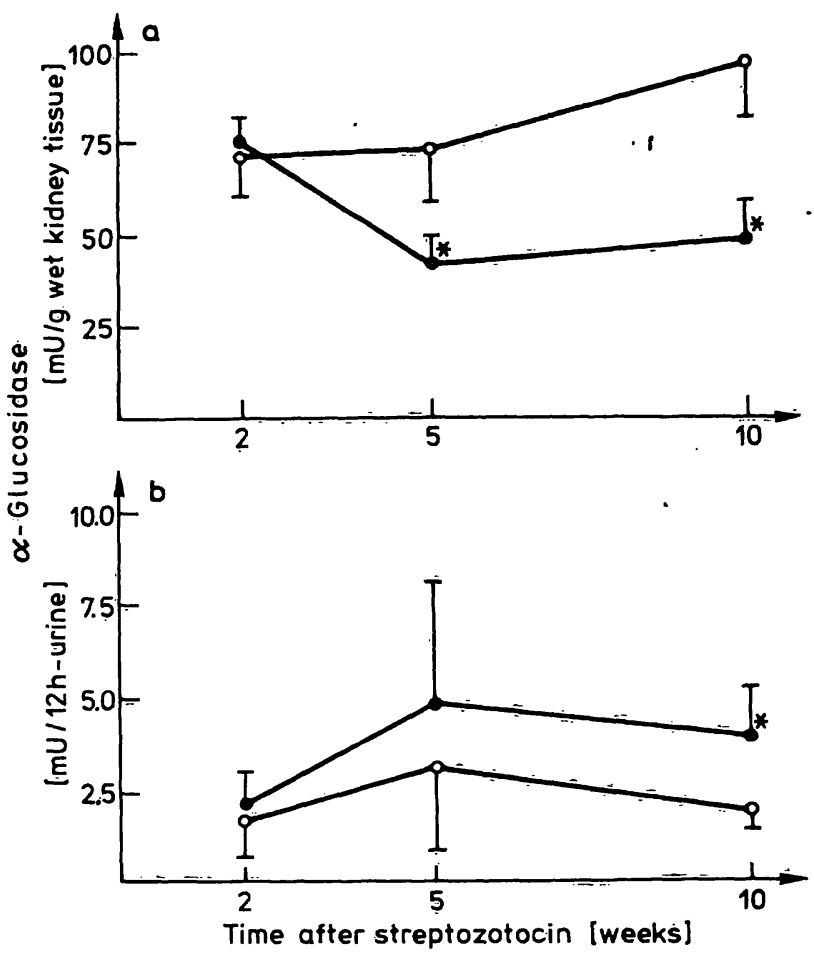

Fig. 4. The catalytic activities of $\alpha$-glucosidase in kidney (a) and urine (b) after streptożotocin administration as a function of time.

Diabetic rats with two weeks of mild hyperglycaemia and severe hyperglycaemia five and ten weeks after treatment (O-O); age-matched controls $(\mathrm{O}-\mathrm{O})$. The values are presented as means $\pm S D$. ${ }^{*}(\mathrm{p}<0.01)$.

ed with insulin Ultralente, it decreased from $21.6 \pm$ 4.36 to $5.77 \pm 1.17 \mathrm{mmol} / \mathrm{l}$. The kidney weight of diabetic rats which were treated by insulin Lente or insulin Ultralente increased above that of the normal age-matched controls. The changes in the glycosidase activities in kidney and in urine are presented as a fraction of the catalytic activity in age-matched controls and are shown in figure $5 \mathrm{a}$ and $5 \mathrm{~b}$. $\mathrm{N}$-acetyl$\beta$ - $D$-glucosaminidase and $\beta$-galactosidase activities in kidneys of diabetic rats treated with insulin Lente (Group 4) were decreased ( $\dot{p}<0.01$ ), while $\alpha$-glucosidase activity was unchanged in relation to the activity of age-matched controls. In contrast to the poorly controlled disease, enzyme catalytic activities in kidney were restored to normal when adequate insulin therapy was applied (fig. 5a). The insulin treatment of diabetes (fig. 5a) caused a rise in $\mathrm{N}$ acetyl- $\beta-D$-glucosaminidase, $\beta$-galactosidase and $\alpha$ glucosidase activities in the kidney, and a consequent decrease of these activities in urine. However, the excretion of $\mathrm{N}$-acetyl- $\beta$ - $D$-glucosaminidase remained above normal (fig. 5b). 
Tab. 2. Effect of the intensity of hyperglycaemia on the activity of glycosidases in kidney and urine two weeks after streptozotocin administration.

$a=$ mild hyperglycaemia; $b=$ severe hyperglycaemia; $N=$ number of rats. The values are presented as means $\pm S D .{ }^{*}(p<0.01)$.

\begin{tabular}{|c|c|c|c|c|c|}
\hline Rat group & $\mathbf{N}$ & $\begin{array}{l}\text { Blood glucose } \\
(\mathrm{mmol} / \mathrm{l})\end{array}$ & $\begin{array}{l}\text { Kidney } \\
\mathrm{N} \text {-acetyl- } \beta \text { - } D \text {-glucos- } \\
\text { aminidase } \\
(\mathrm{mU} / \mathrm{g})\end{array}$ & $\begin{array}{l}\text { Kidney } \\
\beta \text {-galactosidase } \\
(\mathrm{mU} / \mathrm{g})\end{array}$ & $\begin{array}{l}\text { Kidney } \\
\alpha \text {-glucosi- } \\
\text { dase } \\
(\mathrm{mU} / \mathrm{g})\end{array}$ \\
\hline \multirow[t]{2}{*}{$\begin{array}{l}\text { Control } \\
\text { Group } 1 \\
\text { Group } 2\end{array}$} & $\begin{array}{l}6 \\
6 \\
6\end{array}$ & $\begin{array}{r}7.30 \pm 0.69 \\
9.61 \pm 1.36^{\mathrm{a}} \\
21.80 \pm 1.44^{\mathrm{b}}\end{array}$ & $\begin{array}{l}692 \pm 172 \\
623 \pm 155 \\
320 \pm 92^{*}\end{array}$ & $\begin{array}{l}592 \pm 87 \\
625 \pm 78 \\
340 \pm 12^{*}\end{array}$ & $\begin{array}{l}71 \pm 10 \\
74 \pm 7 \\
41 \pm 3^{*}\end{array}$ \\
\hline & & & $\begin{array}{l}\text { Urine } \\
\mathrm{N} \text {-acetyl- } \beta \text { - } D \text {-glucos- } \\
\text { aminidase } \\
(\mathrm{mU} / 12 \mathrm{~h})\end{array}$ & $\begin{array}{l}\text { Urine } \\
\beta \text {-galactosidase } \\
(\mathrm{mU} / 12 \mathrm{~h})\end{array}$ & $\begin{array}{l}\text { Urine } \\
\alpha \text {-glucosi- } \\
\text { dase } \\
(\mathrm{mU} / 12 \mathrm{~h})\end{array}$ \\
\hline $\begin{array}{l}\text { Control } \\
\text { Group } 1 \\
\text { Group } 2\end{array}$ & & & $\begin{array}{l}18.5 \pm 7.98 \\
31.7 \pm 16.6 \\
48.0 \pm 8.15^{*}\end{array}$ & $\begin{array}{l}11.9 \pm 9.27 \\
32.8 \pm 15.0^{*} \\
41.6 \pm 5.12^{*}\end{array}$ & $\begin{array}{l}1.87 \pm 1.22 \\
2.12 \pm 1.04 \\
3.12 \pm 1.58^{*}\end{array}$ \\
\hline
\end{tabular}

Tab. 3. Effect of different types of insulin therapy on the relevant parameters in diabetic rats five weeks after streptozotocin administration.

$N=$ number of rats. The values are presented as means $\pm S D . *(p<0.01)$.

\begin{tabular}{|c|c|c|c|c|c|c|}
\hline $\begin{array}{l}\text { Rat group } \\
\text { No. }\end{array}$ & Therapy & $\mathbf{N}$ & $\begin{array}{l}\text { Blood glucose } \\
\text { (mmol/l) }\end{array}$ & $\begin{array}{l}\text { Urine glucose } \\
(\mathrm{mol} / \mathrm{l})\end{array}$ & $\begin{array}{l}\text { Urine volume } \\
\text { (ml) }\end{array}$ & $\begin{array}{l}\text { Kidney } \\
\text { weight } \\
\text { (g) }\end{array}$ \\
\hline & Control & 12 & $6.23 \pm 1.36$ & $\begin{array}{l}0 \\
>011\end{array}$ & $\begin{array}{r}7.6 \pm 3.2 \\
516+20 ?\end{array}$ & $0.52 \pm 0.04$ \\
\hline $\begin{array}{l}3 \\
4\end{array}$ & $\begin{array}{l}\text { No therapy } \\
\text { Insulin Lente }\end{array}$ & $\begin{array}{r}12 \\
6\end{array}$ & $\begin{array}{l}16.50 \pm 4.38 \\
18.60 \pm 4.50\end{array}$ & $\begin{array}{l}>0.11 \\
>0.11\end{array}$ & $\begin{array}{l}51.6 \pm 20.2 \\
18.2 \pm 6.4\end{array}$ & $\begin{array}{l}0.77 \pm 0.11^{*} \\
0.73 \pm 0.09^{*}\end{array}$ \\
\hline 5 & Insulin Ultralente & 6 & $5.77 \pm 1.17$ & 0 & $10.9 \pm 2.1$ & $0.73 \pm 0.06^{*}$ \\
\hline
\end{tabular}

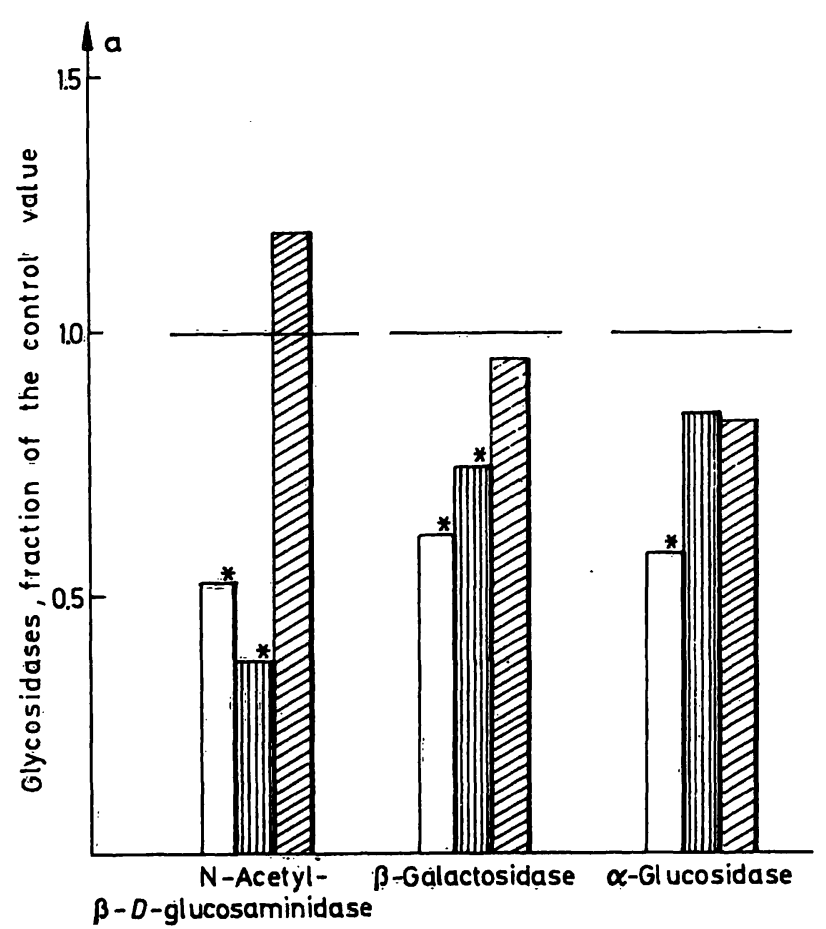

Fig. 5. The effect of therapy on the catalytic activity of glycosidases in kidney (a) and urine (b) five weeks after streptozotocin administration.

$\square$ no therapy; insulin Lente; $\mathbb{a}$ insulin Ultralente; * ( $<0.01 \%$.

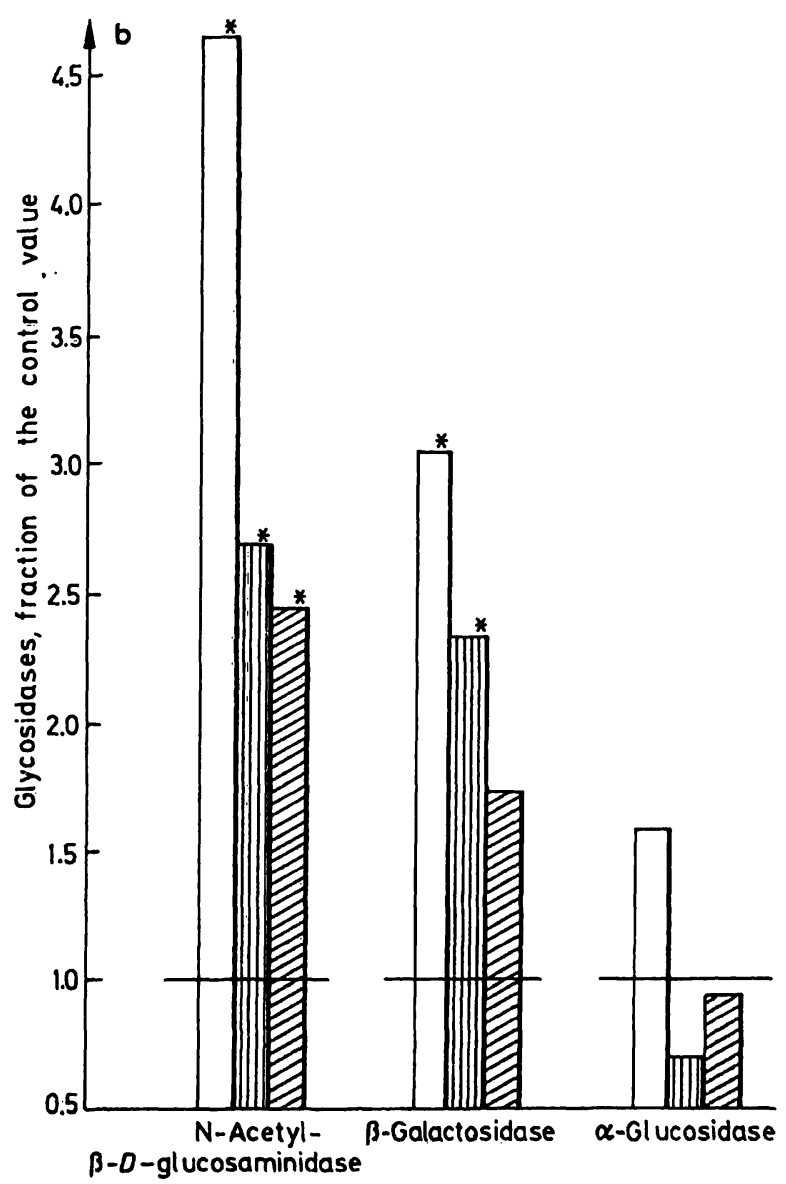




\section{Histological examination}

Light micrographs of renal tissue exhibited the following characteristics:

Glomeruli and tubules were normal and no interstitial or vascular changes were evident in the rats after two weeks of untreated diabetes with mild hyperglycaemia (Group 1). When compared to age-matched controls, glomeruli from Group 3 demonstrated an increase in mesangial PAS-positive material and vacuolization of distal tubules. After ten weeks of life with severe hyperglycaemia, glomeruli showed accumulation of materials, and the normal difference between proximal and distal tubules became undetectable. The group of rats with severe hyperglycaemia two weeks after untreated diabetes (Group 2) showed glomerular and tubular changes similar to those observed in the rats after five weeks of untreated diabetes.

In the groups of diabetic rats, which were supplemented with insulin Lente or insulin Ultralente for three weeks, glomeruli were increased and showed mesangial material in a segmental distribution.

\section{Discussion}

Animal models such as the pancreatectomised rat, the alloxanised or streptozotocin diabetic rat have been widely used in studies related to clinical problems in human diabetes mellitus (11).

Our investigations were performed on diabetic rats whose diabetes had been induced by streptozotocin ( $65 \mathrm{mg} / \mathrm{kg}$ body weight). According to the literature $(12,13,14)$, the induced changes in renal function are similar to the chronic changes in human diabetics and the immediate toxic effects of streptozotocin on kidney are temporary and rather negligible. The experimental model therefore seems appropriate for the study of the effects of hyperglycaemia, and of its therapeutic treatment. The animal model of diabetes was studied by the determination of glycosidases, and by histological analysis of kidney tissue. Not only diabetes, but also ageing causes thickening of the basement membrane (15). In order not to confuse the two triggers of morphological changes we performed our experiments with diabetic and control rats of the same age.

In parallel with the determination of the catalytic activity of glycosidases in kidney and urine, we tested the urine for glucose and proteins with Multistix. In our experiments, proteinuria, which is the basic proof of clinical nephropathy, was not detected.
However, the biochemical and morphological changes in kidney such as nephromegaly and basement membrane thickening appear much earlier (16, 17). This is why it is important to find out whether the excretion of glycosidases in urine in the clinically latent phase of the diabetic nephropathy is indicative of the possible pathological morphological changes in kidney.

According to our results, progress of the model diabetes is accompanied by corresponding biochemical changes (figs. $2,3,4$ ). The rate of development is dependent on the intensity of hyperglycaemia and on the severity of disease (tab. 2). The decrease of the catalytic activity of glycosidases in the kidney is followed by a large increase of $\mathrm{N}$-acetyl- $\beta$ - $D$-glucosaminidase and $\beta$-galactosidase in the urine, which suggests that the determination of these enzymes in urine provides an early indicator of the biochemical status of the kidney in diabetes. Statistically significant excretion of $\alpha$-glucosidase in urine was found in rats with prolonged diabetes when the morphological changes of tubules were already developed. According to Bonini et al. (18) $\alpha$-glucosidase activity in the urine is index of kidney tubular damage. A relatively moderate increase in urinary $\alpha$-glucosidase activity in contrast to high $\mathrm{N}$-acetyl- $\beta-D$-glucosaminidase and $\beta$-galactosidase activities might be due to a direct inhibitory effect of urinary glucose on $\alpha$-glucosidase activity as measured in our assay system (19).

By using different types and modes of application of insulin on our model diabetic system, it was possible to produce different daily variations in the concentrations of blood glucose. This enabled us to establish the effect of the daily variation of blood glucose on the catalytic activity of glycosidases and on the possible reversibility of the already obvious changes. According to the published data, diabetic patients with poorly controlled diabetes often show morphological and functional changes on retina, kidney and other tissues (20). For an inadequate therapy we chose insulin Lente which does not maintain a whole day constant normoglycaemià when applied only once a day. A decrease of $\mathrm{N}$-acetyl- $\beta$ - $D$-glucosaminidase and $\beta$-galactosidase present in kidney seems to indicate that frequent changes of the degree of hyperglycaemia during the day may also cause biochemical and morphological changes similar to that of constant hyperglycaemia during the same period. Lower enzyme catalytic concentrations in the kidney are followed by the increased excretion of $\mathrm{N}=$ acetyl$\beta-\bar{D}$-glucosaminidase and $\beta$-galactosidase in the urine, the excretion being lower at the beginining of the inadequate therapy. This suggests that the mea- 
surement of the activity of these glycosidases in urine is a simple way of monitoring development of kidney damage in poorly controlled diabetes.

One of the encouraging results in the investigation of the nature of pathological changes in the kidneys of diabetics is the possibility of the recovery of the already damaged organ by an adequate and sufficiently early therapy (21). Our experiments were designed to discover whether the activity changes of glycosidases in the starting stage of the disease are reversible. Demonstration of such reversibility would prove the importance of these enzymes in monitoring the efficiency of the therapy. The model for these investigations was the severe hyperglycaemia developed during two weeks after streptozotocin administration, and accompanied by decreased kidney glycosidases. By maintaining constant normoglycaemia for the following three weeks with insulin Ultralente almost normal activities of $\mathrm{N}$-acetyl- $\beta-D$ glucosaminidase, $\beta$-galactosidase and $\alpha$-glucosidase were reestablished. The effect was followed by corresponding decreases of $\beta$-galactosidase and $\alpha$-glucosidase activities in the urine, whereas urinary $N$ acetyl- $\beta$ - $D$-glucosaminidase did not reflect the enzyme situation in the kidney. Instead, the urinary output of this enzyme reflects the persistent morphological alteration in the kidneys of diabetic rats treated by insulin Ultralente. In this group the weight of the kidney and the histologically visible changes in the organ do not seem to differ significantly from those before therapy with insulin Ultralente.

The reason for such an observation might be that the period of therapy of three weeks is too short for a significant improvement of the histological picture.

This interpretation is supported by the results of Rasch $(15,22)$, who maintained a well controlled diabetes for several months in order to demonstrate the decrease of the basement membrane and mesangium regions of the kidney.

\section{References}

1. Osterby, R. \& Gundersen, H. J. (1975) Diabetologia 11, 225-229.

2. Kefalides, N. A. (1974) J. Clin. Invest. 53, 403-411.

3. Spiro, R. G. (1976) Diabetologia 12, 1-14.

4. Khalifa, A. \& Cohen, M. P. (1975) Biochim. Biophys. Acta $386,332-339$.

5. Fushimi, H. \& Tarui, S. (1976) J. Biochem. (Tokyo) 79, 265-270.

6. Mahadevan, D. (1969) Arch. Biochem. Biophys. 129, 525533.

7. Hyvarinen, A. \& Nikkila, B. A. (1962) Clin. Chim. Acta 7, $140-143$.

8. O'Brien, J. S., Okada, S., Chen, A. \& Fillerup, D. L. (1970) New Engl. J. Med. 283, 15-20.

9. Price, R. G., Dance, N., Richards, B. \& Cattell, W. R. (1970) Clin. Chim. Acta 27, 65-72.

10. Salafsky, I. S. \& Nadler, H. L. (1973) J. Lab. Clin. Med. 81, 450-454.

11. Rerup, C. C. (1970) Pharmacol. Rev. 22, 485-518.

12. Maurer, S. M., Steffes, M. W., Michael, A. F. \& Brown, D. M. (1976) Diabetes 25, 850-857.

13. Foy, J. M. \& Salih, A. K. M. (1978) J. Pharm. Pharmacol. 30 , 54P.

14. Carney, S. L., Wong, N. L. M. \& Dirks, J. H. (1979) J. Lab. Clin. Med. 93, 950-961.

15. Rasch, R. (1979) Diabetologia 16, 319-324.

16. Friedman, E. A. \& Beyer, M. M. (1980) Klin. Wochenschr. 58, 1023-1028.

17. Keen, H. \& Viberti, G. C. (1981) J. Clin. Pathol. 34, 12611266.

18. Bonini, P. A., Ceriotti, G. \& Franzini, C. (1970) Clin. Chim. Acta 27, 415-419.

19. Bomback, F. M., Nakagawa, S., Kumin, S. \& Nitowsky, H. M. (1976) Diabetes 25, 420-427.

20. Pirart, J., Lauvaux, J. P. \& Eisendrath, C. (1975) Diabetologia 11,370 .

21. Lee, C. S., Mauer, S. M., Brown, D. M., Sutherland, D. E. R., Michael, A. F. \& Najarian, J. S. (1974) J. Exp. Med. 139, 793-800.

22. Rasch, R. (1979) Diabetologia 16, 185-190.

Dr Dubravka Juretić Institute of Med. Biochem.

Faculty of Pharmacy and Biochemistry

Domagojeva 2

YU-41000 Zagreb 
. . .

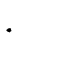

